\title{
Logistic Challenges IN THE SHORT Food Supply CHAINS
}

\author{
András Bence SzERB, Tamás HorváTH, Boglárka SzERB, \\ Arnold CsONKA \\ Kaposvár University, Faculty of Economic Science, H-7400 Kaposvár Guba S. u. 40.
}

\begin{abstract}
The aim of the Paper is to identify the types of short food supply chains (SFSCs), their spread today, and to demonstrate the advantages or disadvantages they provide, especially the logistical problems and solutions that can be identified in the chain. In order to achieve this goal, we carried out a review of international and Hungarian literature sources and secondary data. It can be stated that SFSCs can be a viable alternative to conventional supply chains pursuing a global distribution strategy. Establishing a restricted geographic range of supply provides several benefits to local producers, consumers and society. However, there are serious concerns about logistical costs and associated emissions. To overcome this, there is a need for compromises. The practical example we present shows that the use of conventional, ,less short" sales channels in the distribution mix is reasonable even in the case of local foods.
\end{abstract}

Keywords: short supply chain, food system, logistics

\section{INTRODUCTION}

Nowadays, there is an increasing number of articles in domestic and international literature which concentrate on local products and short food supply chains (SFSCs). The attention paid to local products has started to strengthen decades ago in Western European countries. This has led to the emergence of consumer demand for regionally-produced and traditional food products. Following the positive examples of successful local food and short food supply chains in the French regions, the European Union launched the Euroterroirs program in 1992 to bring French good practice to other countries in the community. This program was not only intended to stimulate local economies, but also to strengthen national identity through the strengthening of traditions (Pannon.Elemzó Iroda, 2010). According to Csonka (2015), since the beginning of the 2000's, the number of local food production systems and the related trademark systems has increased in Hungary and internationally, as well as the volume of transactions carried out in these systems.

To solve the problem of global population growth, conventional food networks and industrialized agriculture have been seeking the answer for a long time. Global trade has been built to distribute the increased amount of food all over the world properly. However, overproduction of agricultural production and food production led to the depletion of farmland and environmental overload. Short food supply 
chains are trying to find solutions to these problems locally. Their focus is on maintaining a healthy person, the environment, the local economy, and local cultural values (Matson et al., 2013). The local food supply chain can cover different sales channels. Producers are typically present in several sales channels in parallel, but according to Mácsai et al. (2012), the traditional „market” is the most important for producers in terms of sales.

The aim of the authors in the study is to identify the types and the popularity of short food supply chains, and to demonstrate the advantages or disadvantages they provide and the logistical problems and solutions that can be identified in the system. In order to achieve this goal, international and Hungarian literature and secondary data sources have been used and analysed

\section{SHORT FOOD SUPPLY CHAIN (SFSC)}

The short food supply chain is defined in different ways by the authors in literature. According to Renting et al. (2003) „... [it] covers (the interrelations between) actors who are directly involved in the production, processing, distribution, and consumption of new food products". In the study, the authors defined the concept of SFSCs in the presence of the following actors as shown in Figure 1. The producers of the products are the farmers who follow the processing level if the nature of product justifies a higher degree of processing. The processors can be the farmers themselves. They are followed by the place of sale and the buyer of the product, the consumer. According to Jarosz (2008), the short food supply chain is characterized by the small size of plant, the small volume and generally the sustainability and the environmental awareness in some form.

\section{Figure 1}

\section{Flow chart of short food supply chain}

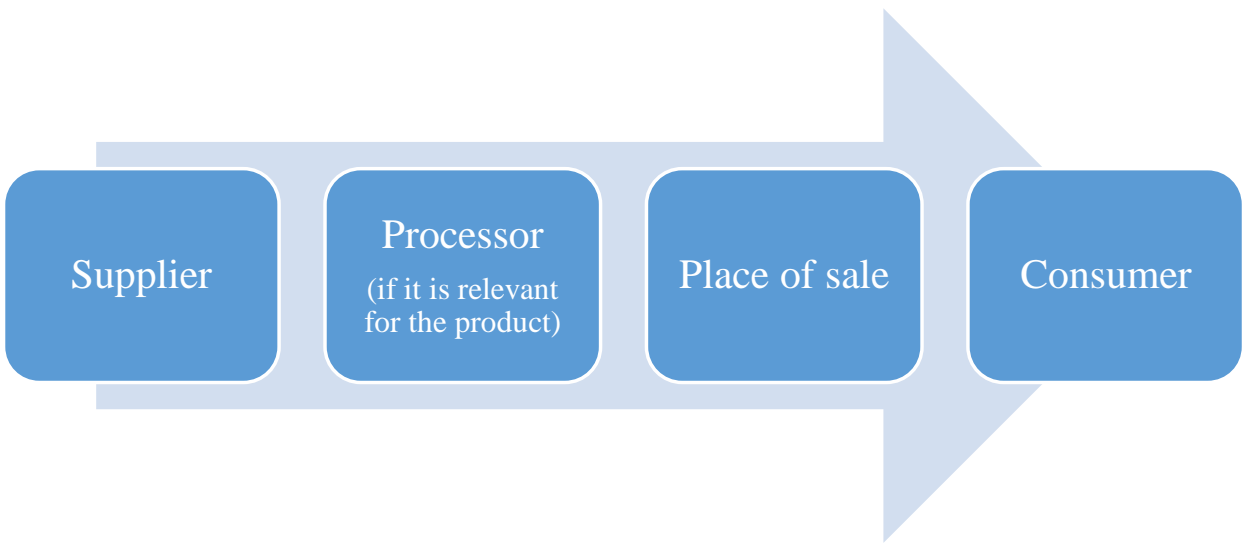

The short food supply chain was divided by Jarosz. (2008) and Ilbery-Maye (2005) into the following types according to their spatial extent and sales mechanism: 


\section{Direct-Connected Sales}

There is a direct contact between the producer and the consumer at the moment of sale. The condition of re-purchase is the good quality of goods and good shopping experience. The place of sale can be: roadside point of sale, home/yard of the farmer/producer, home delivery, producer's market, web store, pick yourself, guest table.

\section{Community Marketing Based Sales}

In case of the community marketing based sales, the relationship between the SFSCs actors is institutionalized. In many studies (Renting et al., 2003; Cleveland et al., 2014) we can read about producer or consumer cooperative shops created by community marketing, which provide an excellent opportunity for producers to appear in the markets. Various direct delivery forms are also popular in local hospitality facilities, in public catering or in local product stores. In recent years, thematic festivals and farewells have been gaining popularity, which can also be the point of appearance for producers.

\section{Extended Supply Chain}

In the case of an extended supply chain, the producer has no direct relationship with the consumer. The most important information is the exact origin of the food (eg. family-business, permaculture, organic, national park or countryside food).

\section{BENEFITS PROVIDED BY SFSC}

\section{Supplier}

According to some international studies (Brehm and Eisenhauer, 2008) about community-supported agricultural systems, farmer's responses indicate lower age and higher education than average. Similar demographic values can usually be found in other supply chain producers. The farms are usually small, the average farm size is less than 10 hectares. The farmers/producers of the short supply system are characterized by flexibility and openness to innovation. It is a difficult task to transform a plant to a level that will enable to participate in a communitysupported farming system, as the consumers expect to provide fresh and varied food continuously. In order to achieve this, SFSCs dependent plants have to develop efficient and flexible operation and communication at the same time (Mastronardi et al., 2015). This is partly due to the fact that the alternative forms are mainly dealt with by young and educated producers. It is also an advantage of the young and educated producers / farmers that joining and existing network requires a wide range of capabilities and tendency to innovate from the producers (Benedek and Balázs, 2014).

Trust is a fundamental condition for the development and success of the short supply system. According to Benedek and Balázs (2014) in Hungary, traditional markets of big settlements, and producers' markets attract different farming layers. In the case of traditional markets, higher prices, instant cash payments, and habits are more important, while in producer's markets the same factors are less 
motivating. On the producer's market, the farmers who sell their products, have larger area and wider range of products and additional investment plans. Cooperative membership and the participation in informal co-operation also have an impact decisions on market sales (Benedek and Fertö, 2015).

\section{Consumer}

The short supply system satisfies the needs of two types of consumers. One of those types basically prefers conventional food supply, and only occasionally uses the possibilities of the short supply system. The other type is completely purposeful for health, ethical or other reasons, and specifically tries to avoid the usual solutions (Nygard and Storstad, 1998; Benedek and Balázs, 2014).

Consumers need to make a serious sacrifice and change their attitude if they want to buy only (or mostly) local food. This kind of sacrifice can be for example giving up non-locally grown fruit and other foods, or occasionally avoiding food that can only be produced locally on account of climatic conditions. In addition, the convenience of supermarkets cannot be forgotten, where everything can be purchased in one place, which is always available to consumers, and in many cases even cheaper (Benedek, 2014). At the same time consumers must know that in the SFSCs the quality of the food is different - probably higher than in the supermarkets - and with their purchase they support the local economy (Brown and Miller, 2008).

\section{Society}

Rural development also plays a significant role in short food supply chains from the point of view of local economic development (McLaughlin and Merrett, 2002). Local producers can become suppliers to local public institutions with the support from the central or local government. A further aim of these catering programs is to improve the health of the children of families with lower income. From the producer's point of view, the advantage of such programs is that a state order can create a predictable, secure market. Local processing increases employment, plus the multiplier effects are that they can strengthen further the local economy (Marsden et al., 2000). Another advantage of the programs is that school classes can take an active part in plant visits and excursions, and that the experiences they have gained will be used in the school or even in the home garden, completing environmental education (Benedek and Balázs, 2014).

\section{POTENTIAL BARRIERS AND HINDERING FACTORS IN THE SFSC}

Beside the benefits of SFSCs there are authors who highlight some factors which can easily turn to barriers in the systems. According to Galli and Brunori (2013) these factors should be solved on different levels: SFSC actors, local administration, national government, EU level.

a. SFSC actors: Having a necessary knowledge from the beginning is very important for the SFSC actors. This knowledge is indispensable for further development or investment as well. For creating an optimum operation actors 
need to invest in networking and communication as well and keep the size of the operation on the appropriate level both from social and economic points of view. Distribution is one of the key factors of the success of SFSCs, so actors should find innovative solutions in reducing these costs through collaboration.

b. Local administration: The good cooperation between SFSCs actors and local administration is required in the system. First of all the behaviour and the mindset of the different administrations should support the local food system. They can support SFSC actors with introducing retailing policies, territorial planning, offering potential market for the products (ex.: local food for children or at public catering) and also introduce a cooperation with public authorities in important questions such as hygienic requirements. Local administration can be a support or one of the biggest barriers for SFSCs.

c. National government and the EU: Rural areas face different problems and therefore they need different kinds of help to solve their problems. The EU and the different national governments have introduced several types of funded projects in the recent years and SFSCs have been able to benefit from these. National governments can use the flexibility of EU rules to help to remove the unnecessary hindrances to SFSC. They can also build SFSCs into multiple policy areas including health, agriculture, rural development and environment to provide a solution for cross departmental policy challenges on local levels.

\section{THE LOGISTIC ISSUES OF THE SFSCS, REGARDING ESPECIALLY THEIR ENVIROMENTAL IMPACT}

The environmental impacts of the short food supply chains are double-edged. It is logical and confirmed by the literature (Soysal et al., 2014; Jarosz, 2008) that short supply distances (either in livestock transport or in the distribution of finished products) associated with local food supply reduce both transport costs and emission of pollutants regarding transport processes. An important environmental advantage of local food systems based on geographical proximity is the reduction of transport distances. At the same time, this advantage can be eliminated by the extra travel cost for consumers. To realize the advantages, therefore, it is necessary to organize efficient and high-quality customer service (eg. environmentally- and user-friendly design of home delivery). Even in the case of special storage conditions (eg. refrigerated storage), there is a possibility that specific energy consumption and emission of pollutants in the SFSCs will exceed the import products. (Benedek, 2014). However, Mundler and Rumpus (2012) emphasize that the energy efficiency on the system level, well-built and managed international transport chains can be even better for small food systems with decentralized operation and smaller sales volume. The balance can clearly tilt towards local supply if the cost of delivering distance between the producer and the consumer is more to the customer, as the chances of organizing multipurpose trips are significantly better on the customer side. In this case, the resulting travel costs are not only „,burdened” by the delivery of the purchased product, but also divided between the additional travel-related goals. This type of transaction can be realized 
directly at the production site or a sales point close to the production site or as part of a community production program typically associated with the settlement. However, there is a serious risk of these kinds of production systems, namely that the producing capacities created for the supply of the single producer or the narrow community can be found in a significant part of the year, with low utilization and with poor efficiency.

The delivery of the product from the place of production to the designated market or to the food centres is the most complicated and cost-effective process. To ensure the smooth running of this process, careful, accurate and precise planning is required. Shipping costs are a very important aspect for the companies. Transport vehicles must be used to their maximum capacity to deliver as many products as possible at the lowest cost. Thus, even large quantities of products can be transported profitably to nearby settlements (Matson et al., 2013; Cleveland et al., 2014). Logistics and short supply system resources are neglected or underestimated despite the fact that logistics has for years been decisively improving the quality of traditional supply systems. There is not only one type of logistics organization in the long supply systems, as it may vary depending on the type of supply and the destination of the product. Warehouses have several main tasks in the supply system: store the product for longer or shorter periods at appropriate temperatures, or label and repackage to deliver further to the target market (Blanquart et al., 2010).

The problems here are serious, but not impossible. The most important question is whether the short food supply chains are backed by the organizational and infrastructure background and the volume of production that can be used to create an efficient logistics system. A good example of this is the Székely trademark created by the Harghita County Council in Romania. The trademark system satisfies both local food system and short supply chains. The system includes food, industrially produced non-food products, handicrafts and intellectual products as well. Effective access to consumers is ensured by a multi-component sales system. The Council organizes a monthly production fair. Consumers can reach the products in concentrated time and space. The cost of travelling to the fair and emissions of pollutants are not only burdened by the purchase of SFSCs products, as other tourist and cultural attractions accompanying the fair are also an important part of the supply. The fairs are organized at regular, predictable intervals, so the purchase becomes well scheduled. Regular local fairs are complemented by the organization of domestic and international festivals and participation in trade fairs, so the products occasionally ,get rid of' the local market, increasing the lifetime and competitiveness of the product. The third element of the sales mix is selling to local shops and chain stores. In addition to guaranteeing a secure market, these commercial companies have an efficient logistics system that enables fast, cheap and low-energy transportation and storage. Because of the use of such conventional sales channels, the trademark system can provide a stable market and economic development for producers. Although this is a compromise on maintaining the SFSCs character of the trademark system, it also allows local improvements for the system. In recent years, a significant amount of processing capacity has been established in Székely Land to increase the added value of the products through 
self-support from the steadily growing sales volume and the inclusion of tender funds. Increasing the level of processing further improves the competitiveness of the products of the trademark system.

\section{CONCLUSION}

In this study, the authors reviewed the peculiarities of short food supply chains, their benefits and logistics challenges. It can be stated that SFSCs can be a viable alternative to supply chains based on conventional industrial production and global distribution strategy. Providing a limited geographic range of supply, with the appropriate level of planning and infrastructure conditions, it offers a lot of advantages to local producers, consumers and society. However, there are serious concerns about logistical costs and related emissions. Several sources that the study have presented show that the low level of organization and technology, the fragmentation of purchasing travels, and the economies of scale resulting from the low volume of transport and the storage capacities ultimately eliminate the benefits of short delivery distances. To overcome this, there is a need for some compromises. The practical examples the study presented shows that the use of conventional „less short” sales channels in the distribution mix can be justified in the case of local foods. The organization and efficiency provided by traditional channels and a stable market enable local development. The example also shows that the success of alternative, SFSCs sales is based on the existence of a strong, high-regulatory background organization capable of operating the SFSCs channels efficiently.

\section{ACKNOWLEDGEMENT}

This research was supported by the EFOP-3.6.2-16-2017-00018 project.

\section{REFERENCES}

Benedek, Z. (2014): A rövid ellátási láncok környezeti hatásai. [online] <URL: http://real.mtak.hu/17217/1/Benedek\%20Zs_A_rovid_ellatasi...MATUD201 4.8.pdf >

Benedek, Z., Balázs, B. (2014). A rövid ellátási láncok szocioökonómiai hatásai. In: Külgazdaság, 58. 5-6. 100-120. p.

Benedek, Z., Fertô, I. (2015): Miért választják a termelők a rövid ellátási láncokat? In: Statisztikai Szemle, 93. 6. 580-597. p.

Blanquart, C., Gonçalves, A., Vandenbossche, L., Kebir, L., Petit, C., Traversac, J.B. (2010): The logistic leverages of short food supply chains performance in terms of sustainability. 12 $2^{\text {th }}$ World Conference on Transport Research 11-15. July, Lisbon, 10. p.

Brehm, J.M., Eisenhauer, B.W. (2008): Motivations for participating in communitysupported agriculture and their relationship with community attachment and social capital. In: Southern Rural Sociology, 23. 1. 94-115. p. 
Brown, C., Miller, S. (2008): The impacts of local markets: a review of research on farmers markets and community supported agriculture (CSA). In: American Journal of Agricultural Economics, 90. 5. 1298-1302. p. doi: 10.1111/j.14678276.2008.01220.x

Csonka A. (2015): A helyi sertéshús ellátás gazdasági lehetőségei magyarországon. In: Élelmiszer, Táplálkozás és Marketing. 11. 1-2. 45-52. p.

Cleveland, D.A., Müller, N.M., Tranovich, A.C., Mazaroli, D.N., Hinson, K. (2014). Local food hubs for alternative food systems: A case study from Santa Barbara County, California. In: Journal of rural studies, 35. 26-36. p. doi: 10.1016/j.jrurstud.2014.03.008

Galli F., Brunori G. (eds.) (2013): Short Food Supply Chains as drivers of sustainable development. Evidence Document. Document developed in the framework of the FP7 project FOODLINKS (GA No. 265287). Laboratorio di studi rurali Sismondi, ISBN 978-88-90896-01-9.

Ilbery, B., Maye, D. (2005): Food supply chains and sustainability: evidence from specialist food producer sin the Scottish/English borders. In: Land Use Policy, 22. 4. 331-344. p. doi: 10.1016/j.landusepol.2004.06.002

Jarosz, L. (2008): The city in the country: Growing alternative food networks in Metropolitan areas. In: Journal of Rural Studies, 24. 3. 231-244. p. doi: 10.1016/j.jrurstud.2007.10.002

Mácsai, É., Kujáni, K., Juhász, A., Hamza, E., Györe, D. (2012): A közvetlen értékesítés szerepe és lehetőségei a hazai élelmiszereke piacra jutásában. Élet a modern kiskereskedelmi csatornákon kívül? In: Juhász A. (ed.): Agrárgazdasági Tanulmányok, Budapest: Agrárgazdasági Kutató Intézet. 121. p. ISSN 14182122

Marsden, T., Banks, J., Bristow, G. (2000): Food supply chain approaches: exploring their role in rural development. In: Sociologia Ruralis, 40. 4. 424-438. p. doi: 10.1111/1467-9523.00158

Mastronardi, L., Marino, D., Cavallo, A., Giannelli, A. (2015): Exploring the role of farmers in short food supply chains: The case of Italy. In: International Food and Agribusiness Management Review, 18. 2. 109-130. p.

Matson, J., Sullins, M., Cook, C. (2013): The role of food hubs in local food marketing. United States Department of Agriculture (USDA) Rural Development Service Report 73 [online] <URL https://www.rd.usda.gov/files/sr73.pdf>

McLaughlin, P., Merrett, C. (2002): Community-supported agriculture: Connecting farmers and communities for rural development. In: Rural Research Report, 13. 1-8. p.

Mundler, P., Rumpus, L., (2012): The energy efficiency of local food systems: A comparison between different modes of distribution. In: Food Policy, 37. 609615. p. doi: 10.1016/j.foodpol.2012.07.006

Nygard, B., Storstad O. (1998): De-globalisation of food markets? Consumer perceptions of safe food: The case of Norway. In: Sociologia Ruralis 38. 1. 3553. p. doi: 10.1111/1467-9523.00062

Pannon.Elemző Iroda (2010): Helyi termékek értékesítési csatornái Magyarországon. Partial study of. „Helyi Kezdeményezésű gazdaságfejlesztési Programok 
Értékesítése". 36.p. [online] <URL: http://hetfa.hu/wp-content/uploads/ 2010/12/Helyi-termékek-értékesitési-csatornái-Magyarországon.pdf>

Renting, H.J., Marsden, T.K., Banks, J. (2003): Understanding alternative food networks: exploring the role of short food supply chains in rural development. In: Environment and planning, 35. 3. 393-412. p. doi: 10.1068/a3510

Soysal, M., Bloemhof-Ruwaard, J., van der Vorst, J.G.A.J. (2014): Modelling food logistics networks with emission considerations: The case of an international beef supply chain. In: International Journal of Production Economics, 152. 5770. p. doi: 10.1016/j.ijpe.2013.12.012

Corresponding author:

\section{Arnold CsONKA}

Kaposvár University, Faculty of Economic Science, H-7400 Kaposvár, Guba S. 40.

Tel.: +36 82505800

email: csonka.arnold@ke.hu 